\title{
Openness to Foreign Direct Investment in Services: An
}

\section{International Comparative Analysis}

\author{
Stephen S. Golub \\ Swarthmore College
}

\section{INTRODUCTION}

32 ATIONAL policies towards FDI typically feature measures aimed at both attracting and discouraging inflows. Policies to attract FDI such as tax breaks, favourable regulatory treatment and subsidies of various sorts are usually focused on manufacturing. ${ }^{1}$ Policies towards services are far more ambivalent. Laws and regulatory practices frequently discriminate against foreign investors in services such as public utilities (electricity distribution and telecommunications in particular), transport (notably air and maritime transport), financial services, and even construction and wholesale/retail distribution.

The ambiguous attitudes towards FDI in services are amply illustrated in recent policy actions and debates. The Committee on Foreign Investment in the United States (CFIUS), an inter-agency group that screens foreign direct investment for national security concerns, has recently been in the limelight with several high-profile cases, notably one involving the acquisition of a US port by investors in Dubai. A recent 'open skies' aviation agreement between the United States and the European Union was scuttled in part because the United States refused to ease its restriction that all US airlines must be at least 75 per cent owned by US citizens. Japan rejected a takeover offer from the UK-based Children's Investment Fund in the energy company J-Power. China has been

The author would like to thank Ching Ling and Brian Tomasik for very helpful research assistance, and an anonymous referee for helpful comments. This paper draws on work done by the author for the OECD (Golub, 2003; Koyama and Golub, 2006) and UNCTAD (UNCTAD, 2006), but all views expressed are personal.

${ }^{1}$ See Moran et al. (2005). 
moving, under pressure from the United States, to open its financial services industry to foreign investors. Likewise, India is also gradually opening wholesale and distribution services to large foreign firms such as Wal-Mart despite strong local opposition. Venezuela and other Latin American countries with left-wing governments, on the other hand, have recently increased restrictions on foreign investment in telecommunications. Thailand has also recently moved to reduce control by foreign investors in its telecommunications industry. ${ }^{2}$

As in the case of manufacturing, countries benefit from FDI in services through employment creation, capital accumulation, transfer of technology, improved service and increased competition. Moreover, liberalisation of FDI in services can contribute to manufacturing productivity by increasing availability of quality of production-related services (Arnold et al., 2006, 2007; Golub et al., 2007). Critics argue that FDI can also impose economic costs such as displacement of local firms and reduced competition. Infant 'entrepreneurship' arguments can be adduced in favour of discrimination against foreign investors. Service sectors are also typically subject to economic or prudential regulation, because of tendencies towards natural monopoly or other market failures, although such market failures do not in themselves provide a clear-cut rationale for discrimination between local and foreign investors. The main reasons for limiting foreign ownership in services are non-economic, relating to national security or economic nationalism. Industries such as telecommunications, banking, transportation and electricity provision are often viewed by host countries as 'strategic' or 'sensitive'. Services are therefore generally subject to far more stringent restrictions than manufacturing and even natural resources (Hoekman, 1995).

The cross-border provision of services, unlike goods, often can only be delivered through 'commercial presence', i.e. setting up of foreign operations, rather than international trade in the item itself. It is therefore to be expected that FDI plays a prominent role in the globalisation of the service sector, fostered in part by partial opening of service industries to FDI.

Formal international agreements on FDI and on trade in services have been far less extensive than on international trade in goods, although various global negotiations and regional free-trade agreements often cover some aspects of international investment in services, notably the General Agreement on Trade in Services (GATS) provisions on commercial presence. ${ }^{4}$ To the extent that it has occurred, opening to FDI in services has primarily been unilateral.

\footnotetext{
${ }^{2}$ See, for example, A. Beattie, S. Kirchgaessner and R. Minder, 'Left in the Cold', Financial Times, 25 April 2008, and other Financial Times articles.

${ }^{3}$ See UNCTC (1989, pp. 132-35) and UNCTAD (2004) for discussion of this issue.

${ }^{4}$ See Graham (2000), Sauvé and Wilkie (2000) and Robertson (2002) for discussion of international agreements on investment.
} 
TABLE 1

FDI Stocks by Industry, 1990 and 2005 (US\$ billion)

\begin{tabular}{|c|c|c|c|c|}
\hline & \multicolumn{2}{|l|}{1990} & \multicolumn{2}{|l|}{2005} \\
\hline & Developed & Developing & Developed & Developing \\
\hline Primary & 140 & 28 & 551 & 239 \\
\hline Manufacturing & 584 & 145 & 2,197 & 779 \\
\hline Services & 714 & 155 & 4,684 & $1,029^{*}$ \\
\hline Electricity, Gas, Water & 7 & 3 & 171 & 56 \\
\hline Wholesale and Retail Trade & 187 & 24 & 871 & 200 \\
\hline Transport and Communications & 15 & 12 & 407 & 149 \\
\hline Finance & 272 & 87 & 1,516 & 362 \\
\hline Business Services & 103 & 14 & 1,069 & $142 *$ \\
\hline \multirow[t]{4}{*}{ Total } & 1,437 & 328 & 7,432 & 2,047 \\
\hline & \multicolumn{4}{|c|}{ Per Cent of Region Total } \\
\hline & \multicolumn{2}{|l|}{1990} & \multicolumn{2}{|l|}{2005} \\
\hline & Developed & Developing & Developed & Developing \\
\hline Primary & $9.7 \%$ & $8.5 \%$ & $7.4 \%$ & $11.7 \%$ \\
\hline Manufacturing & $40.6 \%$ & $44.2 \%$ & $29.6 \%$ & $38.0 \%$ \\
\hline Services & $49.7 \%$ & $47.3 \%$ & $63.0 \%$ & $50.3 \%$ \\
\hline Electricity, Gas, Water & $0.5 \%$ & $0.8 \%$ & $2.3 \%$ & $2.7 \%$ \\
\hline Wholesale and Retail Trade & $13.0 \%$ & $7.4 \%$ & $11.7 \%$ & $9.7 \%$ \\
\hline Transport and Communications & $1.1 \%$ & $3.7 \%$ & $5.5 \%$ & $7.3 \%$ \\
\hline Finance & $18.9 \%$ & $26.7 \%$ & $20.4 \%$ & $17.7 \%$ \\
\hline Business Services & $7.2 \%$ & $4.3 \%$ & $14.4 \%$ & $6.9 \%$ \\
\hline
\end{tabular}

Note:

*Excluding Hong Kong holding countries.

Source: UNCTAD, World Investment Report 2007, Table A.I.9.

FDI in services has been increasing rapidly, raising the stakes in the debates about policies. In 2005, services constituted the majority of inward FDI stocks, at almost two-thirds for developed countries, and about 50 per cent for developing countries, up considerably from 1990 (Table 1). Within services, finance, trade and business services are the three largest categories, but transport, communications and electricity have also been increasing rapidly. It should be noted, however, that the share of services in total FDI remains smaller than the share of services in world GDP, reflecting in part the fact that FDI in services remain relatively restricted. Evidence that restrictions reduce FDI is provided below. 
Despite the increasing prominence and controversies surrounding FDI in services, very little systematic information is available on policies towards FDI in services. Unlike international trade where international comparisons of tariff and non-tariff barriers are widely available, there have been few previous efforts to quantify and systematically compare national policies towards FDI. Yet, indicators of the policy stance towards FDI are just as important as measures of trade barriers, given the prominence of FDI in the world economy and the policy debates surrounding FDI. Both policy-makers and researchers stand to benefit from the use of the indicators presented here. The first step in any international negotiations related to FDI involves improved information on policies towards FDI. The influential knowledge-capital model of FDI suggests that restrictions on FDI are an important variable for inclusion in empirical analysis. In econometric tests of FDI, researchers have sometimes resorted to measures based on surveys of investor opinion, rather than objective measures of openness to FDI, but the reliability of these subjective measures is open to question. ${ }^{5}$

Case studies of the environment for FDI in various economies have been conducted through investors surveys and country reports (e.g. Economist Intelligence Unit reports and Country Commercial Guides), but these cover a wide variety of issues and are not easily compared.

Given the difficulties in classifying and ranking the various restrictions, some studies (e.g. Hoekman, 1995) are limited to counting the number of restrictions. Kobrin (2005) used an annual UNCTAD report on national policy changes to show that liberalisation measures greatly outnumber increased restrictions in the 1992-2001 period. However, UNCTAD's database provides no information about the level of restrictions, only the number and nature of changes that are observed in different years.

A number of studies of restrictions on FDI (Hoekman, 1995; Pacific Economic Cooperation Council, 1995) use the WTO's GATS commitments related to mode 3 (commercial presence) as their primary data source. GATS commitments are made in the form of 'positive' lists, i.e. they represent official commitments to open markets. This is in contrast to 'negative' lists of exceptions to liberalisation. ${ }^{6}$ A problem with the GATS positive lists is that the absence of a positive commitment in some sector does not necessarily imply a restriction. A country may simply have chosen not to list this sector in its schedule to retain policy flexibility. Or, if the sector is restricted, GATS may be silent on the nature of the

\footnotetext{
${ }^{5}$ See Markusen and Maskus (2001) for a survey.

${ }^{6}$ A positive list consists of a set of industries open to inward FDI, with all others presumed closed. A negative list consists of an explicit set of reservations or exceptions from openness to FDI, with all other industries presumed to be open to inward FDI.
} 
restriction. Also, the current GATS schedules date from around 2000 and may not adequately capture recent changes at the national level.

The Australian Productivity Commission and affiliated researchers carried out a number of sectoral studies of impediments to trade in services: telecommunications (Warren, 2001), banking (McGuire and Schuele, 2001), maritime transport (McGuire et al., 2001), distribution (Kalirajan, 2000) and professional services (Nguyen-Hong, 2000). These studies focus on all modes of service delivery rather than FDI per se, however, and many of them rely primarily on the GATS, with the related limitations noted above.

The Heritage Foundation Index of Economic Freedom (IEF) rates the openness of countries to FDI on a scale of 1 to 5. The IEF methodology is not clearly articulated on their website and covers broader aspects of the climate for FDI, such as foreign exchange convertibility and access to arbitration that differ from the narrower focus here on discrimination between foreign and domestic investors. The World Competitiveness Report also ranks countries on their openness to FDI. These reports, however, are not based on a transparent and verifiable method and openness to FDI is not precisely defined.

Hardin and Holmes $(1997,2002)$ provide a comprehensive approach to barriers to inward FDI but cover only a limited number of countries. Golub (2003), Koyama and Golub (2006) and UNCTAD (2006) adopt a variant of Hardin and Holmes's approach in a study of restrictions on inward FDI for various samples of developed and developing countries. This article extends and synthesises the results from these three studies.

There are a number of limitations of the present study. First, policies towards FDI are diverse and complex, and therefore not easily quantified even when they are known. Second, descriptions of these policies are not readily available and must be sought in a variety of sources, which sometimes provide conflicting or incomplete information. Third, policies are not static; on the contrary, governments have frequently altered policies. Fourth, the focus here is on policies that discriminate between foreign and domestic investors, i.e. deviations from 'national treatment'. Regulations of labour and product markets and other policies that apply equally to foreign and domestic investors are not considered here, with the exception of government monopolies. For example, domestic content requirements, price ceilings, prudential regulations and other barriers to entry are not addressed. Fifth, this study is limited to overt restrictions on FDI, mostly ignoring any informal private or official efforts to tilt the playing field in favour of domestic over foreign firms. Sixth, the breadth and degree of enforcement may not always be easily inferred from the descriptions of the statutes. Seventh, this study does not consider 'positive' discrimination towards foreign investors such as tax breaks.

The remainder of the paper is organised as follows. Section 2 explains the method of computing FDI restrictions, Section 3 presents the results for all 
countries, Section 4 examines the correlations of FDI restrictions with FDI patterns, and Section 5 concludes.

\section{METHODOLOGY ${ }^{7}$}

This section explains how measures of policies discriminating between foreign and domestic investors are computed. There are several issues involved in computing the restriction scores. A classification of various types of restrictions, a choice of industries and a system of weighting are needed.

\section{a. Classification and Scoring of Policies}

Restrictions can be separated into those affecting market entry and those affecting post-entry operations. ${ }^{8}$ The former is emphasised here, given the predominance and importance of policies restricting entry. Post-entry national treatment is much more widely accepted and institutionalised than the right of establishment (UNCTAD, 2003, Ch. 5).

Restrictions of entry can take the form of limitations on foreign ownership and screening requirements. Ownership restrictions specify permissible maximum foreign equity participation, ranging from a complete ban on foreign holdings to allowing 100 per cent foreign ownership. Usually, ownership limitations are applicable to a particular industry. Screening requirements, on the other hand, often apply to all sectors. Screening can vary widely in its stringency, from routine notification and automatic approval to a national interest test where the foreign investor has to make a case for entry rather than the government having to justify denying entry. Post-entry operational discrimination against foreign-owned firms is more diverse. In the service sector, the main such restrictions are stipulations regarding the nationality and citizenship of managers or board members, limits to temporary entry of expatriate personnel, and other nationality requirements for staff.

Overall restrictiveness is measured on a scale from 0 to 1 , with 0 representing full openness and 1 a de facto or actual prohibition of FDI. Table 2 presents the weights, using the three types of restrictions: ownership, screening and post-entry operational. Given their evident importance, ownership restrictions receive a substantial weight. In the case of a ban on foreign ownership, other

\footnotetext{
${ }^{7}$ This section draws on Golub (2003), Koyama and Golub (2006) and UNCTAD (2006).

${ }^{8}$ See UNCTAD (2003, Ch. 5) for a discussion of the distinction between pre- and post-entry national treatment.
} 
TABLE 2

FDI Restriction Scoring Method

\begin{tabular}{ll} 
Foreign Ownership & \\
No foreign equity allowed & 1 \\
$1-19 \%$ foreign equity allowed & 0.6 \\
20-34\% foreign equity allowed & 0.5 \\
$35-49 \%$ foreign equity allowed & 0.4 \\
$50-74 \%$ foreign equity allowed & 0.2 \\
75-99\% foreign equity allowed & 0.1 \\
Screening and Approval & \\
Investor must show economic benefits & 0.2 \\
Approval unless contrary to national interest & 0.1 \\
Notification (pre- or post-) & 0.05 \\
Operational Restrictions & \\
Board of Directors/Managers & \\
$\quad$ majority must be nationals or residents & \\
at least 1 must be national or resident & 0.1 \\
Duration of Work Permit for Expatriates & 0.05 \\
less than one year & \\
$\quad$ one to two years & 0.1 \\
three to four years & 0.05 \\
Other Operational Restrictions & 0.025 \\
Total (capped at 1.0) & up to 0.1 \\
\hline
\end{tabular}

restrictions become irrelevant. ${ }^{9}$ The ownership scores in Table 2 are constructed so as to capture non-linearities in ownership restrictions as well as the inverse relationship between permissible foreign equity share and restrictiveness. A complete ban on ownership is much more restrictive than allowing even a small foreign shareholding. Also, allowing majority foreign ownership (51 per cent foreign equity) is considerably less restrictive than a limitation to 49 per cent foreign equity or less. ${ }^{10}$

Screening is perhaps most subject to ambiguity in determining the extent of restrictiveness, as the extent of enforcement or interpretation of approval procedures is difficult to determine from the statutes. Clearly, however, simple notification is less restrictive than an approval requirement. An effort was made to determine whether approval is generally granted, in which case the score is 0.1 or is subject to a national interest test, in which case the score is 0.2 .

\footnotetext{
${ }^{9}$ The index is capped at 1 . As may be inferred from Table 2, it is possible that the component restriction scores could sum to more than 1 even if foreign equity is not banned, without the cap. ${ }^{10}$ The scoring of equity restrictions differs slightly in Golub (2003) and Koyama and Golub (2006) compared to UNCTAD (2006), so the former were adjusted to be consistent with the latter.
} 
As noted above, the focus is on departures from national treatment rather than regulatory barriers hampering market access for both domestic and foreign firms. An exception is made for government monopoly or near-monopoly, however, as government monopoly is in effect a ban on FDI. Industries reserved for the government are scored as though ownership is banned. Where government ownership was determined to be greater than 50 per cent, a partial ownership restriction was imputed. ${ }^{11}$

Other formal restrictions that can discourage FDI inflows include constraints on the ability of foreign nationals either to manage or to work in affiliates of foreign companies and other operational controls on these businesses. Stipulations that nationals or residents must form a majority of the board of directors may undermine foreign owners' control over their holdings and hence make them more hesitant to invest. Similarly, regulations restricting the duration of employment of foreign nationals can reduce the attractiveness of a country to foreign firms. Other operational restrictions can apply to particular sectors or to all services. For example, in transportation, cabotage (domestic transport services) is often limited to domestically-owned firms.

\section{b. Industries and Weights}

Given that restrictions are often specific to a particular industry, a high level of disaggregation is necessary. The list of industries is shown in Table 3 . The sectors included are those which are most commonly involved in FDI and services trade and subject to restrictions. Social services such as education and health were not included in this analysis. ${ }^{12}$

Various alternative weights were considered to aggregate the sub-sectors into a national total, including FDI and GDP weights. FDI-based weights are clearly

${ }^{11}$ The restriction score was calculated as follows:

$\begin{array}{ll}\text { Government Ownership Share } & \text { Score } \\ \text { State monopoly } & 1.0 \\ \text { Privatisation under way } & 0.6 \\ 90 \text { per cent or more } & 0.4 \\ 75-90 \text { per cent } & 0.2 \\ \text { Majority } & 0.1\end{array}$

These scores are intended to reflect the fact that a government monopoly is equivalent to a ban on foreign ownership, but substantial government ownership does not necessarily preclude increased foreign ownership in the future. Thus, current large government ownership shares may be consistent with large new greenfield FDI or even mergers and acquisitions if privatisation is under way and no other restrictions on foreign ownership apply. These scores are therefore intended to roughly capture the extent to which large state ownership in effect impedes foreign participation.

${ }^{12}$ Education, health and environmental services were considered in the UNCTAD (2006) study. 
TABLE 3

Service Industries and Sub-industries and Weights

\begin{tabular}{lll}
\hline Sectors & Weights & \\
\cline { 2 - 3 } & Sector & Sub-sector \\
\hline $\begin{array}{l}\text { Business services } \\
\quad \text { Legal }\end{array}$ & 0.28 & 0.50 \\
$\quad$ Accounting & & 0.50 \\
Telecommunications & 0.06 & \\
$\quad$ Fixed-line telecommunications & & 0.75 \\
$\quad$ Mobile telecommunications & & 0.25 \\
Construction & 0.03 & \\
$\begin{array}{l}\text { Distribution } \\
\text { Electricity (generation, distribution) }\end{array}$ & 0.13 & \\
$\begin{array}{l}\text { Financial } \\
\text { Insurance }\end{array}$ & 0.03 & \\
$\quad$ Banking & 0.23 & \\
Tourism & & 0.77 \\
$\begin{array}{l}\text { Transport } \\
\text { Maritime } \\
\text { Air }\end{array}$ & & 0.23 \\
Road & 0.01 & \\
\hline
\end{tabular}

Source: Adapted from Golub (2003).

pertinent, but use of actual FDI flows raises a problem of endogeneity: highly restricted sectors may experience less FDI and hence receive too low a weight. An alternative is to use GDP weights, but some service sectors with large shares of GDP such as health, education and other social services are subject to very little FDI. Consequently, FDI weights appear preferable to GDP weights. To mitigate the endogeneity issue, however, an average of FDI and trade weights was employed using OECD data taken from Golub (2003). The inclusion of cross-border trade in the weighting scheme may be justified insofar as crossborder trade can substitute for FDI when the latter is restricted. The weights are shown in Table $3 .{ }^{13}$ Sensitivity analysis in Golub (2003) and UNCTAD (2006)

\footnotetext{
${ }^{13}$ For the business services and telecommunications sub-sectors, weights are based on a priori judgments as no FDI or trade data were available. 
TABLE 4

Country Coverage, by Region

\begin{tabular}{|c|c|c|}
\hline \multirow{2}{*}{$\frac{\text { Developed }}{\text { Western Europe }}$} & \multicolumn{2}{|c|}{ Developing and Transition } \\
\hline & Sub-Saharan Africa & East Asia \\
\hline Australia & Ethiopia & China \\
\hline Austria & Kenya & Indonesia \\
\hline Belgium & Mauritius & Korea \\
\hline Denmark & Nigeria & Malaysia \\
\hline Finland & Senegal & Mongolia \\
\hline France & South Africa & Philippines \\
\hline Germany & Tanzania & Thailand \\
\hline \multicolumn{3}{|l|}{ Greece } \\
\hline Iceland & Latin America & Eastern Europe \\
\hline Ireland & Argentina & Czech Rep. \\
\hline Italy & Bolivia & Estonia \\
\hline Netherlands & Brazil & Hungary \\
\hline Norway & Chile & Latvia \\
\hline Portugal & Costa Rica & Lithuania \\
\hline Spain & Dominican Republic & Poland \\
\hline Sweden & El Salvador & Romania \\
\hline Switzerland & Guatemala & Russia \\
\hline \multirow[t]{2}{*}{ United Kingdom } & Jamaica & Serbia \\
\hline & Mexico & Slovakia \\
\hline Other Developed & Paraguay & Slovenia \\
\hline Australia & Peru & Turkey \\
\hline Canada & Trinidad \& Tobago & \\
\hline Japan & Uruguay & Middle East/N. Africa \\
\hline New Zealand & & Algeria \\
\hline \multirow[t]{6}{*}{ United States } & South Asia & Egypt \\
\hline & India & Israel \\
\hline & Pakistan & Morocco \\
\hline & Sri Lanka & Qatar \\
\hline & & Saudi Arabia \\
\hline & & Tunisia \\
\hline
\end{tabular}

showed that use of value-added weights instead of FDI-trade weights had very little effect on the country rankings. ${ }^{14}$

\section{c. Countries}

This study covers 73 developed and developing countries around the world, corresponding to those included in Koyama and Golub (2006) and UNCTAD (2006). The choice of countries was determined by data availability. Table 4 presents the countries included in the study, by region.

${ }^{14}$ See Golub (2003, Fig. A2) and UNCTAD (2003, Table A3). 


\section{d. Data Sources}

There is no comprehensive source of information on national FDI policies. The data used here pull together and harmonise the data from Golub (2003) and Koyama and Golub (2006) for developed countries and UNCTAD (2006) for developing countries. These studies are based on a large number of alternative sources from various international organisations and the private sector, which are themselves derived from surveys of national regulations. Developed-country data span 1980-2006 while the developing-country data are limited to 2004-05. The underlying data sources are described in the Appendix.

\section{RESULTS}

Before presenting the results, the limitations should again be acknowledged. Systematic classification and quantification of FDI restrictions is complicated due to the disparate nature and inconsistent reporting of restrictions across countries. Despite efforts to rely on multiple sources and objective reports, there is an unavoidable element of arbitrariness and subjectivity to the scoring. There is no international agreement on standardised reporting of policies towards FDI in services, with the partial exception of the GATS schedules. There are occasional inconsistencies in some of the different sources. It can therefore be argued that the restriction scores for the services sector as a whole may be more accurate than the scores for individual industries, insofar as errors in the latter may be smoothed out in the overall score. Overall, the results should be interpreted as estimates rather than precise and definitive findings. It is also possible that some countries are more forthcoming than others in self-reporting their restrictions. It could then be that more transparent countries receive higher scores, not because they are in fact more restrictive, but because they are more complete in their reporting. Nevertheless, the results presented here are the most comprehensive and rigorous available and are also validated by their correlations with FDI patterns, reported below.

\section{a. Overall Results}

Table 5 presents the summary results by principal industry and for the service sector as a whole. Figure 1 shows the overall scores in ascending order of restrictiveness.

The total services restrictions vary considerably across countries from a low of 0.1 or below for Latvia, the United Kingdom, Belgium, the Netherlands, Germany, Jamaica, Italy, Ireland, Argentina and Bolivia, to more than 0.5 in the Philippines, Indonesia, Ethiopia, Saudi Arabia, Qatar and Malaysia. Ownership 
TABLE 5

FDI Restrictions Index by Sector, 2004-05 (0-1 scale, $0=$ open, $1=$ closed $)$

\begin{tabular}{|c|c|c|c|c|c|c|c|c|c|}
\hline & Business & Communication & Construction & Distribution & Electricity & Finance & Tourism & Transport & All Services \\
\hline Algeria & 0.10 & 0.40 & 0.10 & 0.10 & 0.70 & 0.33 & 0.10 & 0.30 & 0.23 \\
\hline Argentina & 0.10 & 0.10 & 0.10 & 0.10 & 0.10 & 0.10 & 0.10 & 0.10 & 0.10 \\
\hline Australia & 0.20 & 0.42 & 0.20 & 0.20 & 0.60 & 0.28 & 0.20 & 0.42 & 0.29 \\
\hline Austria & 0.40 & 0.18 & 0.18 & 0.26 & 0.18 & 0.20 & 0.18 & 0.43 & 0.31 \\
\hline Belgium & 0.03 & 0.08 & 0.03 & 0.09 & 0.28 & 0.08 & 0.03 & 0.14 & 0.08 \\
\hline Bolivia & 0.05 & 0.33 & 0.05 & 0.05 & 0.15 & 0.10 & 0.05 & 0.14 & 0.10 \\
\hline Brazil & 0.25 & 0.45 & 0.15 & 0.15 & 0.65 & 0.47 & 0.15 & 0.40 & 0.34 \\
\hline Canada & 0.23 & 0.48 & 0.23 & 0.23 & 0.73 & 0.20 & 0.23 & 0.38 & 0.28 \\
\hline Chile & 0.15 & 0.20 & 0.10 & 0.10 & 0.10 & 0.20 & 0.10 & 0.37 & 0.21 \\
\hline China & 0.29 & 0.45 & 0.15 & 0.45 & 0.45 & 0.43 & 0.15 & 0.58 & 0.42 \\
\hline Colombia & 0.26 & 0.50 & 0.10 & 0.20 & 0.40 & 0.30 & 0.20 & 0.10 & 0.24 \\
\hline Costa Rica & 0.10 & 1.00 & 0.05 & 0.05 & 1.00 & 0.35 & 0.13 & 0.39 & 0.29 \\
\hline Czech Republic & 0.18 & 0.06 & 0.05 & 0.03 & 0.30 & 0.13 & 0.03 & 0.12 & 0.13 \\
\hline Denmark & 0.13 & 0.08 & 0.03 & 0.09 & 0.68 & 0.08 & 0.03 & 0.16 & 0.13 \\
\hline Dominican Rep. & 0.15 & 0.15 & 0.15 & 0.15 & 0.35 & 0.53 & 0.15 & 0.48 & 0.32 \\
\hline Ecuador & 0.13 & 0.65 & 0.10 & 0.10 & 0.45 & 0.15 & 0.10 & 0.15 & 0.17 \\
\hline Egypt & 0.15 & 0.68 & 0.45 & 0.15 & 0.80 & 0.38 & 0.35 & 0.29 & 0.29 \\
\hline El Salvador & 0.25 & 0.25 & 0.15 & 0.15 & 0.15 & 0.31 & 0.15 & 0.23 & 0.24 \\
\hline Estonia & 0.51 & 0.02 & 0.02 & 0.02 & 0.62 & 0.05 & 0.02 & 0.28 & 0.24 \\
\hline Ethiopia & 0.13 & 1.00 & 0.15 & 1.00 & 1.00 & 1.00 & 0.40 & 0.41 & 0.59 \\
\hline Finland & 0.11 & 0.11 & 0.11 & 0.16 & 0.76 & 0.11 & 0.11 & 0.32 & 0.18 \\
\hline France & 0.04 & 0.08 & 0.03 & 0.13 & 0.30 & 0.09 & 0.03 & 0.17 & 0.10 \\
\hline Germany & 0.03 & 0.08 & 0.03 & 0.09 & 0.13 & 0.09 & 0.03 & 0.18 & 0.09 \\
\hline Ghana & 0.25 & 0.25 & 0.25 & 0.35 & 1.00 & 0.33 & 0.25 & 0.25 & 0.30 \\
\hline Greece & 0.05 & 0.13 & 0.03 & 0.13 & 1.00 & 0.12 & 0.03 & 0.22 & 0.14 \\
\hline Guatemala & 0.10 & 0.10 & 0.10 & 0.10 & 0.30 & 0.12 & 0.10 & 0.10 & 0.11 \\
\hline Hungary & 0.11 & 0.14 & 0.10 & 0.11 & 0.25 & 0.13 & 0.10 & 0.26 & 0.16 \\
\hline Iceland & 0.33 & 0.08 & 0.33 & 0.39 & 1.00 & 0.33 & 0.33 & 0.38 & 0.35 \\
\hline India & 0.20 & 0.45 & 0.35 & 0.65 & 0.15 & 0.47 & 0.13 & 0.37 & 0.38 \\
\hline Indonesia & 1.00 & 0.35 & 0.58 & 0.35 & 1.00 & 0.52 & 0.65 & 0.46 & 0.62 \\
\hline Ireland & 0.03 & 0.13 & 0.03 & 0.08 & 1.00 & 0.09 & 0.03 & 0.10 & 0.10 \\
\hline
\end{tabular}




\begin{tabular}{|c|c|c|c|c|c|c|c|c|c|}
\hline Israel & 0.10 & 0.25 & 0.05 & 0.05 & 0.65 & 0.05 & 0.05 & 0.26 & 0.14 \\
\hline Italy & 0.03 & 0.08 & 0.03 & 0.09 & 0.10 & 0.16 & 0.03 & 0.12 & 0.09 \\
\hline Jamaica & 0.10 & 0.05 & 0.05 & 0.05 & 0.05 & 0.12 & 0.13 & 0.09 & 0.09 \\
\hline Japan & 0.25 & 0.48 & 0.15 & 0.15 & 0.15 & 0.19 & 0.15 & 0.36 & 0.26 \\
\hline Kenya & 0.35 & 0.50 & 0.33 & 0.33 & 1.00 & 0.50 & 0.33 & 0.33 & 0.40 \\
\hline Korea & 0.21 & 0.48 & 0.20 & 0.25 & 0.24 & 0.35 & 0.14 & 0.42 & 0.31 \\
\hline Latvia & 0.00 & 0.00 & 0.00 & 0.00 & 1.00 & 0.00 & 0.00 & 0.07 & 0.04 \\
\hline Lithuania & 0.05 & 0.05 & 0.05 & 0.05 & 0.65 & 0.09 & 0.05 & 0.17 & 0.10 \\
\hline Malaysia & 0.68 & 0.50 & 0.20 & 0.60 & 1.00 & 0.40 & 0.60 & 0.45 & 0.53 \\
\hline Mexico & 0.34 & 0.49 & 0.11 & 0.22 & 1.00 & 0.36 & 0.21 & 0.43 & 0.37 \\
\hline Mongolia & 0.15 & 0.35 & 0.15 & 0.10 & 0.30 & 0.15 & 0.05 & 0.17 & 0.16 \\
\hline Morocco & 0.25 & 0.13 & 0.15 & 0.05 & 0.75 & 0.05 & 0.08 & 0.53 & 0.25 \\
\hline Mozambique & 0.20 & 0.80 & 0.20 & 0.20 & 1.00 & 0.20 & 0.20 & 0.20 & 0.26 \\
\hline Netherlands & 0.03 & 0.03 & 0.03 & 0.03 & 0.60 & 0.09 & 0.03 & 0.17 & 0.09 \\
\hline New Zealand & 0.13 & 0.43 & 0.13 & 0.13 & 0.10 & 0.13 & 0.13 & 0.32 & 0.19 \\
\hline Nigeria & 0.05 & 0.13 & 0.05 & 0.55 & 1.00 & 0.13 & 0.30 & 0.05 & 0.17 \\
\hline Norway & 0.12 & 0.07 & 0.07 & 0.12 & 0.82 & 0.12 & 0.07 & 0.36 & 0.19 \\
\hline Paraguay & 0.00 & 0.75 & 0.15 & 0.00 & 1.00 & 0.14 & 0.00 & 0.15 & 0.14 \\
\hline Peru & 0.14 & 0.13 & 0.13 & 0.13 & 0.13 & 0.16 & 0.13 & 0.26 & 0.17 \\
\hline Philippines & 1.00 & 0.50 & 0.60 & 0.30 & 0.60 & 0.65 & 0.50 & 0.55 & 0.67 \\
\hline Poland & 0.16 & 0.42 & 0.06 & 0.16 & 0.27 & 0.29 & 0.06 & 0.17 & 0.21 \\
\hline Portugal & 0.10 & 0.18 & 0.08 & 0.14 & 0.83 & 0.17 & 0.08 & 0.21 & 0.17 \\
\hline Qatar & 0.40 & 0.40 & 0.40 & 0.40 & 0.42 & 1.00 & 0.35 & 0.40 & 0.54 \\
\hline Romania & 0.13 & 0.10 & 0.00 & 0.00 & 1.00 & 0.20 & 0.00 & 0.36 & 0.20 \\
\hline Russia & 0.10 & 0.40 & 0.10 & 0.10 & 0.20 & 0.72 & 0.15 & 0.33 & 0.32 \\
\hline Saudi Arabia & 0.25 & 1.00 & 0.45 & 0.55 & 1.00 & 0.55 & 0.26 & 0.79 & 0.56 \\
\hline Senegal & 0.10 & 0.24 & 0.10 & 0.10 & 0.20 & 0.15 & 0.15 & 0.10 & 0.12 \\
\hline Slovakia & 0.23 & 0.07 & 0.07 & 0.07 & 0.32 & 0.17 & 0.07 & 0.19 & 0.17 \\
\hline Slovenia & 0.18 & 0.25 & 0.05 & 0.05 & 0.35 & 0.17 & 0.05 & 0.74 & 0.29 \\
\hline South Africa & 0.15 & 0.59 & 0.15 & 0.15 & 1.00 & 0.22 & 0.15 & 0.24 & 0.24 \\
\hline Spain & 0.12 & 0.28 & 0.08 & 0.13 & 0.48 & 0.17 & 0.08 & 0.26 & 0.18 \\
\hline Sri Lanka & 0.11 & 0.28 & 0.05 & 0.35 & 0.65 & 0.35 & 0.13 & 0.64 & 0.35 \\
\hline Sweden & 0.12 & 0.17 & 0.07 & 0.07 & 0.57 & 0.12 & 0.07 & 0.18 & 0.14 \\
\hline Switzerland & 0.09 & 0.15 & 0.08 & 0.09 & 0.90 & 0.13 & 0.08 & 0.43 & 0.20 \\
\hline
\end{tabular}


TABLE 5 Continued

\begin{tabular}{|c|c|c|c|c|c|c|c|c|c|}
\hline & Business & Communication & Construction & Distribution & Electricity & Finance & Tourism & Transport & All Services \\
\hline Tanzania & 0.18 & 0.18 & 0.18 & 0.38 & 0.18 & 0.18 & 0.18 & 0.18 & 0.20 \\
\hline Thailand & 0.45 & 0.55 & 0.45 & 0.35 & 1.00 & 0.55 & 0.35 & 0.35 & 0.46 \\
\hline Trinidad \& Tobago & 0.20 & 0.65 & 0.15 & 0.15 & 0.05 & 0.15 & 0.60 & 0.32 & 0.23 \\
\hline Tunisia & 1.00 & 0.89 & 0.16 & 0.46 & 1.00 & 0.16 & 0.31 & 0.16 & 0.50 \\
\hline Turkey & 0.14 & 0.22 & 0.18 & 0.23 & 0.65 & 0.25 & 0.13 & 0.45 & 0.27 \\
\hline Uganda & 0.10 & 0.10 & 0.10 & 0.10 & 0.10 & 0.15 & 0.10 & 0.10 & 0.11 \\
\hline UK & 0.03 & 0.03 & 0.03 & 0.09 & 0.03 & 0.09 & 0.03 & 0.15 & 0.08 \\
\hline Uruguay & 0.00 & 0.83 & 0.00 & 0.00 & 1.00 & 0.43 & 0.03 & 0.17 & 0.22 \\
\hline USA & 0.05 & 0.40 & 0.05 & 0.05 & 0.50 & 0.15 & 0.05 & 0.54 & 0.22 \\
\hline Venezuela & 0.83 & 0.15 & 0.15 & 0.15 & 0.45 & 0.22 & 0.15 & 0.15 & 0.36 \\
\hline
\end{tabular}

Source: Author's calculations (see text). 
Index Restrictions on FDI in Services, 2004-05 (0-1 scale, $0=$ open, $1=$ closed)

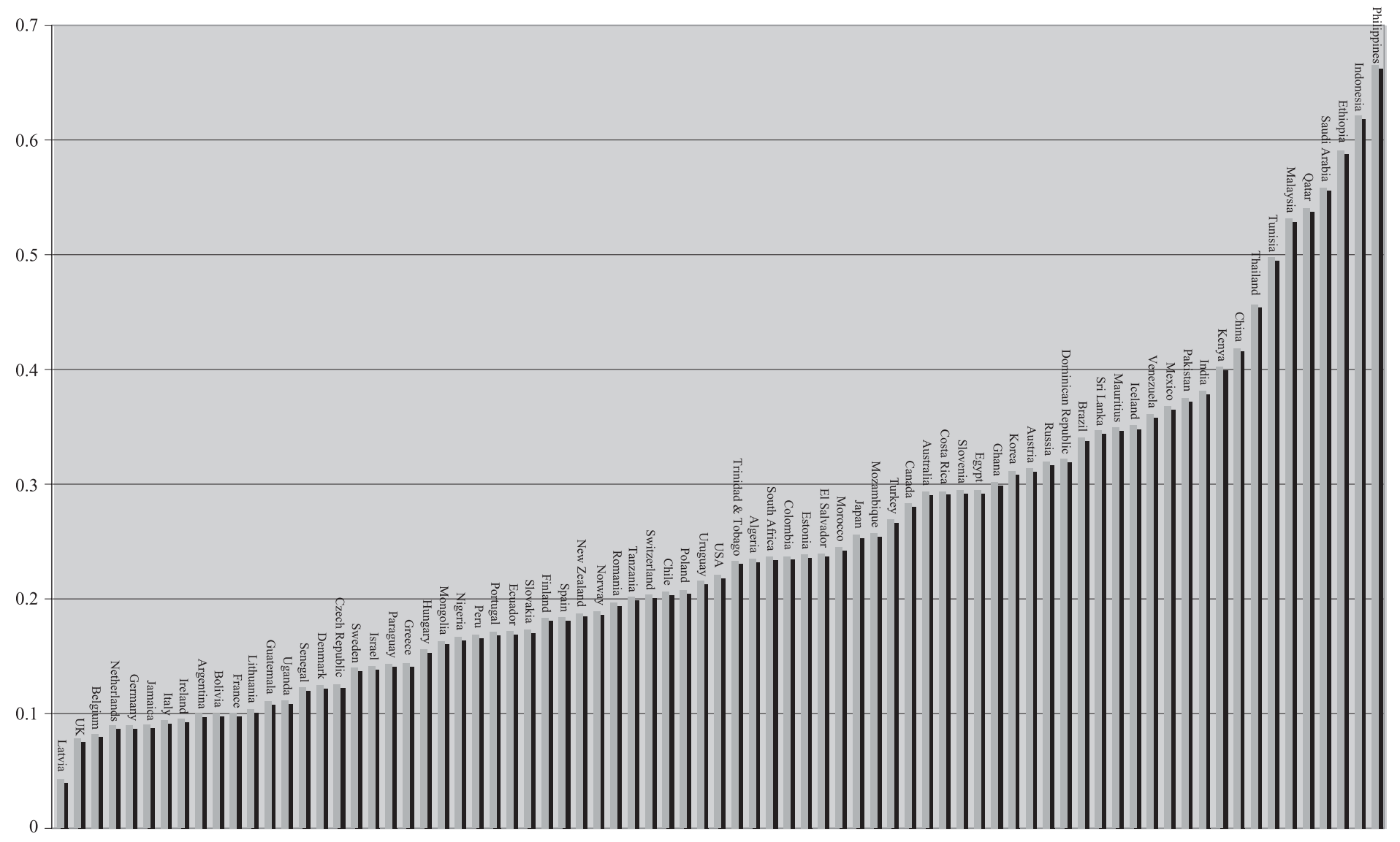


FIGURE 2

FDI Restrictions by Sector, Developed and Developing Countries, 2004-05

$(0-1$ scale, $0=$ open, $1=$ closed $)$

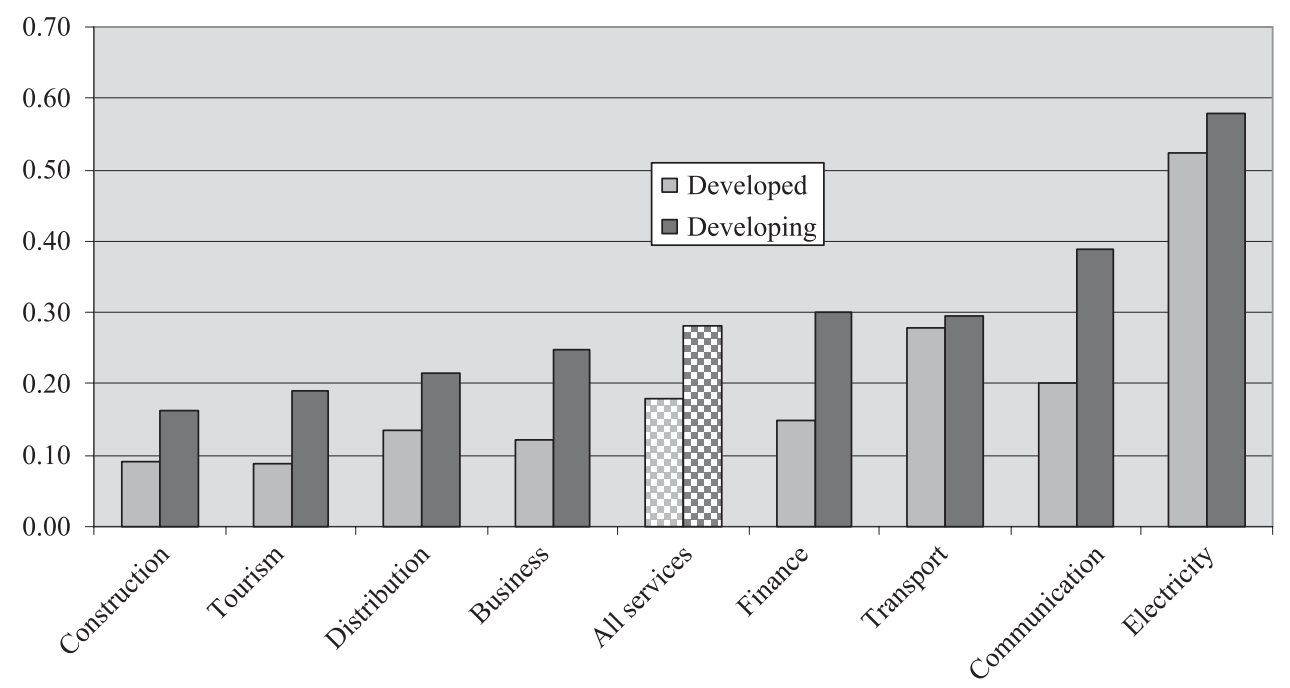

limits account for the bulk of the restriction score in most countries, especially those with higher scores, i.e. the variation across countries are primarily explained by differences in ownership restrictions. For example, in countries like Saudi Arabia, Ethiopia and several Asian countries, a large number of service industries are subject to stringent ownership restrictions.

\section{b. Results by Industry and Region}

Figure 2 shows industry-based simple averages across the sample, split into developed and developing countries. Developing countries on average are more restrictive than developed countries, although the extent varies by sector. The differential restrictiveness between developing and developed countries is most marked in telecommunications and finance, and least in electricity and transport. The electricity, telecommunications, transport and finance sectors are the industries in which FDI is most heavily restricted, in both developed and developing countries. Business services, distribution, tourism and construction are less restricted than the average for all sectors included in the sample.

Figure 3 displays averages by region, for all services. Notwithstanding considerable national variations within regions, there are marked differences between regions. The lowest restriction scores are in Europe, both developed Western Europe and developing Eastern Europe, and Latin America, as the previous discussion of individual country scores suggested. In Western Europe, the European Union countries have almost completely liberalised FDI flows amongst themselves 
FIGURE 3

FDI Restrictions by Region (Simple Averages), All Services, 2004-05

$(0-1$ scale, $0=$ open, $1=$ closed $)$

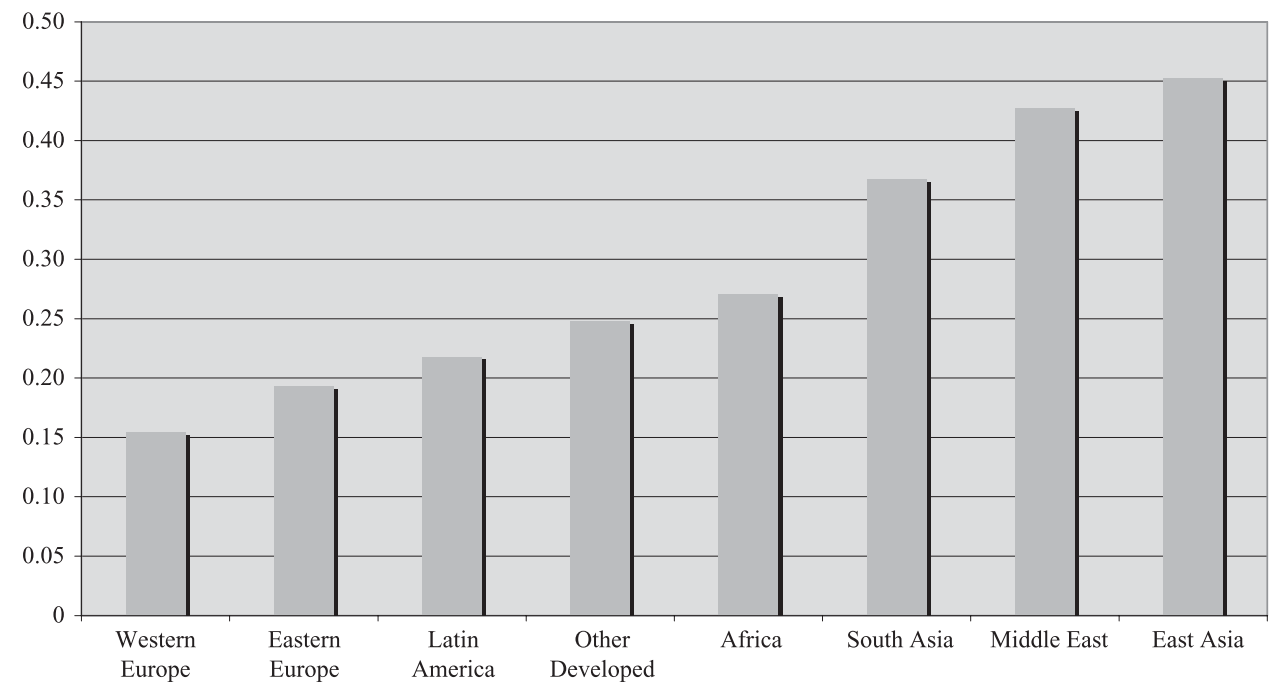

and have also reduced barriers to FDI from non-EU countries. ${ }^{15}$ Eastern Europe and Latin America have embraced 'Washington Consensus' liberalisation to a greater extent than other regions, including dismantling barriers to inward FDI. East Asia, South Asia and the Middle East, on the other hand, are the most closed regions. It may seem surprising that East Asian developing countries such as Thailand, Malaysia, Indonesia, China and Korea, known for their success in export-led growth, have rather high barriers to inward FDI ${ }^{16}$ This seeming anomaly reflects the selective attitude towards FDI in these countries: mostly welcoming towards manufacturing and export-oriented FDI while maintaining a more restrictive policy stance with regard to FDI in services. Africa displays greater national diversity than other regions, with some countries very highly restricted (Ethiopia, Kenya), while others have low levels of restrictions (Uganda, Senegal).

\section{c. Trends over Time}

Time-series information is only available for developed countries, based on Golub (2003) and Koyama and Golub (2006). Figure 4 shows the evolution of

\footnotetext{
${ }^{15}$ The European scores adjust for preferences granted to intra-EU investment. These adjustments consist of scaling down European country scores in cases where such intra-European preferences are granted in a proportion equal to the share of intra-EU investment in total inward investment in the EU.

${ }^{16}$ The East Asian scores may be affected by the exclusion of Hong Kong, Singapore and Taiwan from the sample.
} 
FIGURE 4

Trends in FDI Restrictions over Time, All Services and Selected Sectors, Developed Countries $(0-1$ scale, $0=$ open, $1=$ closed $)$

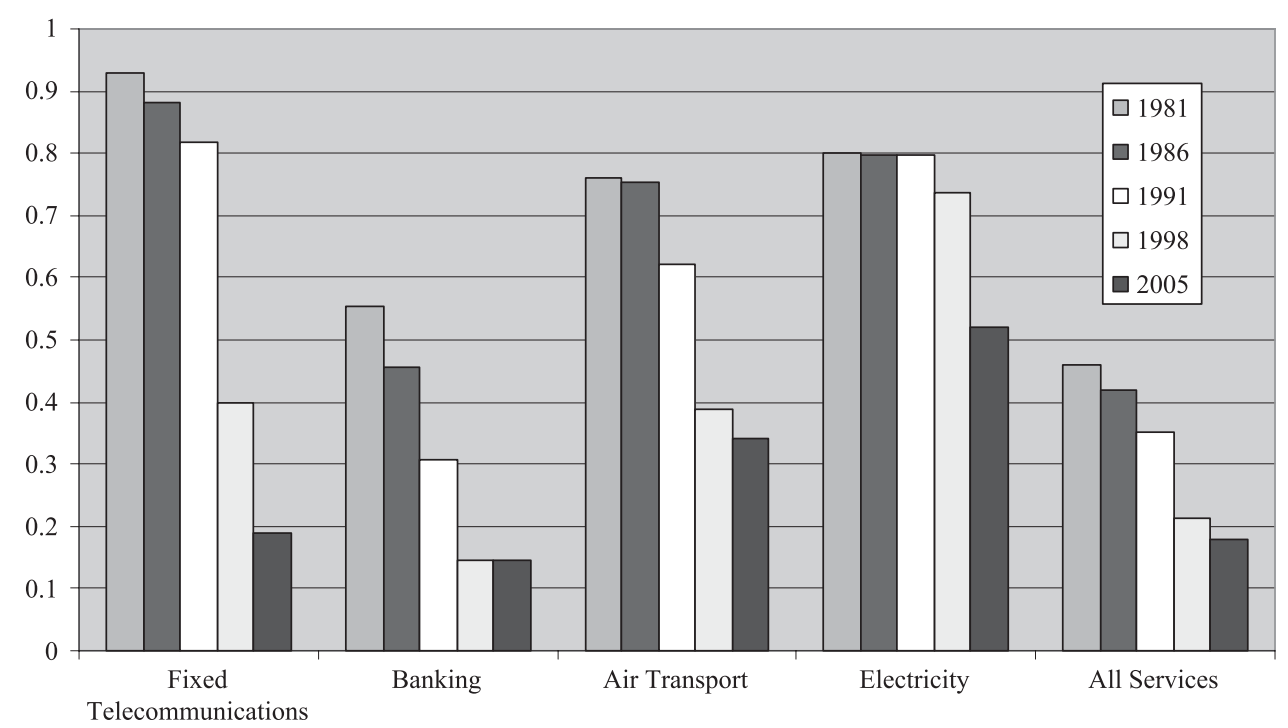

restrictions over time for the developed-country average for services as a whole and for selected sub-sectors. ${ }^{17}$ As expected, restrictions on FDI have been relaxed considerably over time, although the extent varies considerably by sector. For services as a whole, the restrictiveness indicator dropped from close to 0.5 in the early 1980s to below 0.2 in 2005 , with the largest declines occurring in the 1990s. Electricity generation and distribution remains quite highly restricted, having seen only a moderate easing. On the other extreme, fixed-line telecommunications has witnessed a dramatic decline in restrictiveness as countries have opened up their previous national monopolies to competition, including through foreign investment. Banking and air transport, two other highly sensitive sectors, have been substantially opened up, although air transport remains relatively restricted.

Figure 5 and Table 6 show the change in restrictions over 1981-2005 by country. It can be observed that restrictions on FDI have decreased markedly over time for most countries. The changes have been particularly dramatic in several European countries, notably Portugal, France, Norway and Finland, reflecting the substantial liberalisation of FDI flows within Europe. A major exception is the United

\footnotetext{
${ }^{17}$ Koyama and Golub (2006) modified the method of computation used in Golub (2003) in some respects. The results reported here are based on the method used in Golub (2003) with the scores in Koyama and Golub (2006) recalculated accordingly. Calculations were carried out for 1981, 1986, 1991, 1998 and 2005. Results for other years can be obtained through interpolation. The full dataset is available from the author upon request.
} 
FIGURE 5

FDI Restrictions in Developed Countries, 1981 and 2005

$(0-1$ scale, $0=$ open, $1=$ closed $)$

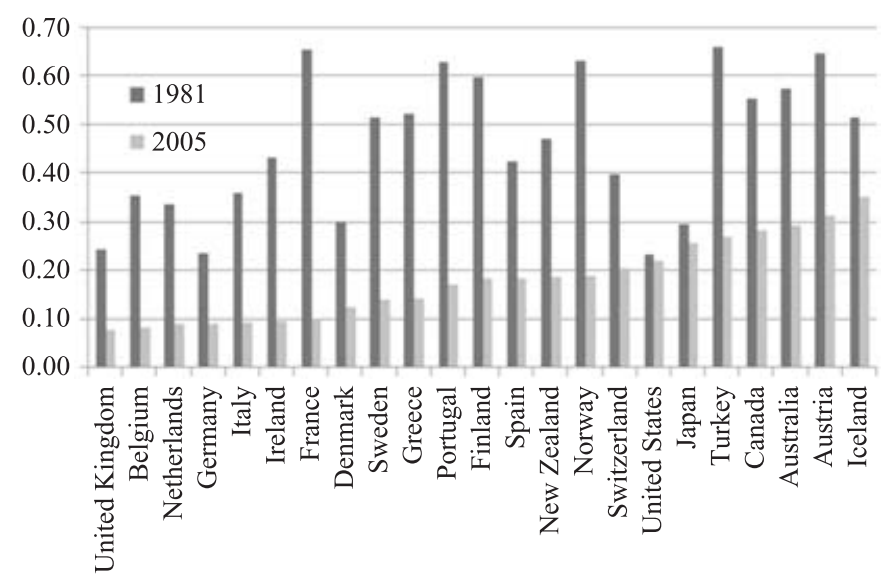

TABLE 6

FDI Restrictions in Developed Countries, 1981-2005

$(0-1$ scale, $0=$ open, $1=$ closed $)$

\begin{tabular}{llllll}
\hline & 1981 & 1986 & 1991 & 1998 & 2005 \\
\hline Australia & 0.57 & 0.57 & 0.35 & 0.30 & 0.29 \\
Austria & 0.65 & 0.65 & 0.65 & 0.34 & 0.31 \\
Belgium & 0.35 & 0.35 & 0.35 & 0.12 & 0.08 \\
Canada & 0.55 & 0.55 & 0.41 & 0.34 & 0.28 \\
Denmark & 0.30 & 0.26 & 0.21 & 0.13 & 0.13 \\
Finland & 0.60 & 0.60 & 0.49 & 0.21 & 0.18 \\
France & 0.65 & 0.41 & 0.29 & 0.15 & 0.10 \\
Germany & 0.24 & 0.24 & 0.22 & 0.11 & 0.09 \\
Greece & 0.52 & 0.52 & 0.39 & 0.18 & 0.14 \\
Iceland & 0.51 & 0.51 & 0.51 & 0.42 & 0.35 \\
Ireland & 0.43 & 0.34 & 0.31 & 0.10 & 0.10 \\
Italy & 0.36 & 0.36 & 0.36 & 0.13 & 0.09 \\
Japan & 0.29 & 0.28 & 0.27 & 0.26 & 0.26 \\
Netherlands & 0.33 & 0.33 & 0.30 & 0.11 & 0.09 \\
New Zealand & 0.47 & 0.47 & 0.24 & 0.22 & 0.19 \\
Norway & 0.63 & 0.59 & 0.56 & 0.24 & 0.19 \\
Portugal & 0.63 & 0.38 & 0.26 & 0.20 & 0.17 \\
Spain & 0.42 & 0.39 & 0.27 & 0.21 & 0.18 \\
Sweden & 0.51 & 0.38 & 0.38 & 0.18 & 0.14 \\
Switzerland & 0.40 & 0.36 & 0.36 & 0.22 & 0.20 \\
Turkey & 0.66 & 0.66 & 0.52 & 0.47 & 0.27 \\
United Kingdom & 0.24 & 0.19 & 0.17 & 0.08 & 0.08 \\
United States & 0.23 & 0.23 & 0.22 & 0.22 & 0.22 \\
Average of all countries & 0.46 & 0.42 & 0.35 & 0.21 & 0.18 \\
\hline
\end{tabular}


States, which in the early 1980s had the lowest restriction measure but was in the middle of the pack by the late 1990s. This reflects the fact that there have been almost no changes in the United States, while other countries have greatly liberalised access to foreign investment. In the early 1980s, a number of countries had total restriction scores in the $0.4-0.6$ range.

Although no systematic data are available on time trends in developing-country FDI restrictions, UNCTAD and OECD Investment Policy Reviews as well as the UNCTAD policy changes database (Kobrin, 2005) indicate that substantial liberalisation has also occurred in developing countries, again mostly in the 1990s.

As the introduction to this paper indicated, in 2007 and 2008 several countries imposed new restrictions on FDI, but others have continued to liberalise. The net effect of these recent policy changes is not covered in the present indicators.

\section{CORRELATION OF FDI RESTRICTIONS AND FDI STOCKS}

Data on stocks of inward FDI in services were obtained from UNCTAD's electronic STATFI FDI database for 2004 or the latest year available for around 30 countries in the sample. Figure 6 displays a scatterplot of logarithm of FDI stocks in the service sector, scaled by population, and the computed FDI restrictions, indicating a strong negative correlation.

\section{FIGURE 6}

Scatterplot of FDI Stocks in Services (as a Ratio to Population) and FDI Restriction Scores for All Services, 2004-05

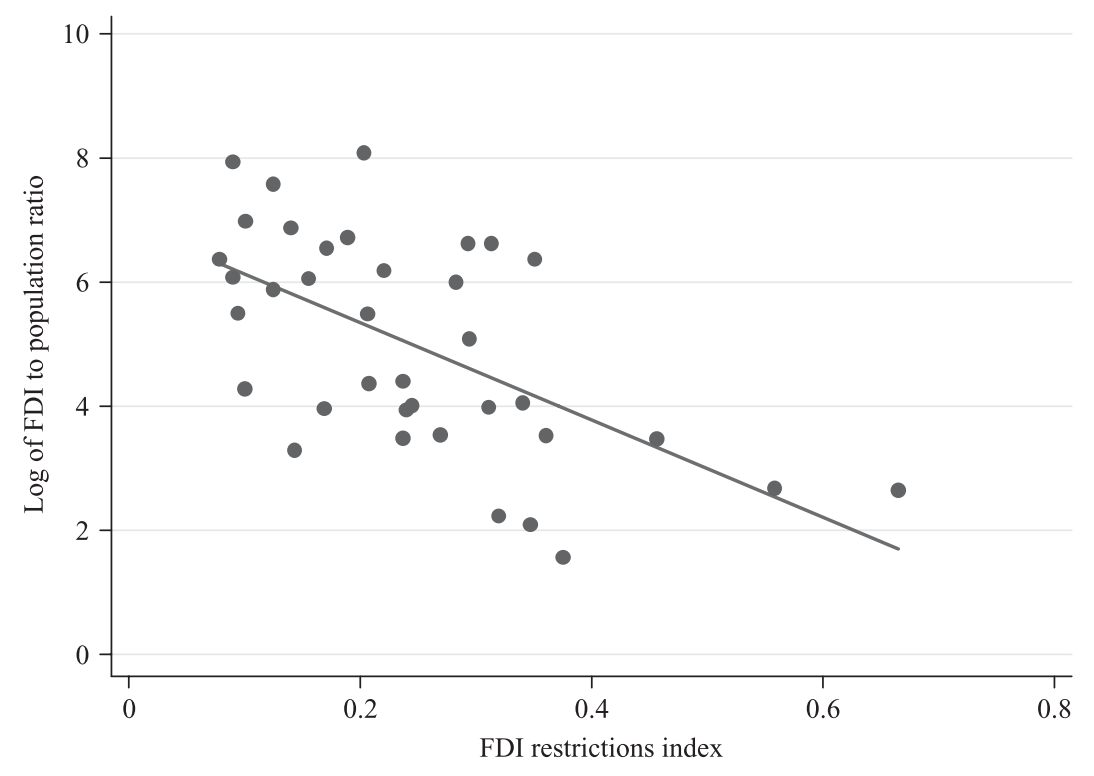


Multivariate cross-section regressions, using some of the standard variables considered in the literature on determinants of FDI, such as GDP per capita, infrastructure and corruption, confirmed the effect of FDI restrictions on FDI inward stocks, but the regression analysis is limited by the small number of observations, and the results are not reported here. ${ }^{18}$

\section{CONCLUSIONS}

Almost all countries now welcome foreign investment in export-oriented manufacturing. The service sector, however, tends to be subject to more restrictions on foreign holdings, notwithstanding substantial liberalisation in the past two decades. This paper has sought to document and analyse the pattern of restrictions in the service sector for a large group of developed and developing countries. Indices of barriers to foreign ownership as well as operational restrictions towards foreign firms were computed at a detailed sectoral level and aggregated into an overall national indicator.

Despite the limitations of this study, it represents the most comprehensive and in-depth compilation of policies towards FDI in services. Moreover, the indicators of restrictiveness are validated by their strong negative correlation with FDI stocks, suggesting both that the indicators are broadly accurate and that they matter for FDI determination.

The most heavily restricted industries are those that are highly sensitive to national security or national sovereignty considerations: telecommunications, transport, finance and electricity. There is also wide dispersion in the extent of openness towards FDI in services between and within regions. The most open countries tend to be in Eastern and Western Europe and Latin America. East Asia, South Asia and the Middle East tend to have greater restrictions on FDI.

\section{APPENDIX: DATA SOURCES}

\section{a. GATS Commitments}

The World Trade Organization website contains the GATS commitments (http://tsdb.wto.org/wto/WTOHomepublic.htm). Mode 3 (commercial presence) restrictions are sometimes noted in the GATS horizontal (all sectors) and sector commitments, although these are 'positive' rather than 'negative' lists.

\footnotetext{
${ }^{18}$ The regression results are available from the author upon request.
} 


\section{b. UNCTAD Sources}

UNCTAD Survey. Thirty-one countries responded to a survey conducted by UNCTAD in 2004, which consisted of a table to be filled out regarding restrictions for each sector listed, and a questionnaire on the nature of restrictions. Of the 31 respondents, 27 were used in the sample. In four cases answers were incomplete and/or could not be corroborated by outside sources, and were not used.

UNCTAD Regulatory Framework $(R F)$ is carried out for the UNCTAD Investment Compass, a guide to the investment climate in UNCTAD member countries.

UNCTAD Investment Policy Reviews (IPRs) are country studies carried out on an irregular basis examining member country policies in considerable detail, resulting in a published monograph available online. These monographs contain a chapter on the legal environment affecting FDI.

\section{c. OECD Sources}

OECD Directorate on Financial and Fiscal Affairs (DAFFE) has compiled a list of reservations from the code of liberalisation of capital movements in OECD (2005a). Earlier studies of OECD-wide policies (OECD, 1982, 1987, 1992) were the foundation for the time-series computations of FDI reported here.

Like UNCTAD, the OECD publishes Investment Policy Reviews, similar in nature to UNCTAD's IPRs. Recently, the OECD has issued a number of IPRs for non-member countries, including Brazil, China, Russian Federation, Slovenia, Caribbean Basin (Costa Rica, Jamaica and the Dominican Republic) and Romania.

The OECD has recently released an analysis of the Regulatory Environment for Foreign Direct Investment in Africa (OECD, 2005b) in conjunction with the African NEPAD initiative. This study contains a list of policies towards FDI for 11 African countries, 10 of which were included in the present study.

The restrictions reported to the OECD under the abortive Multilateral Agreement on Investment (MAI) were made available to the author as part of the research for Golub (2003).

\section{d. US Government Sources}

The United States Special Trade Representative (USTR) issues the National Trade Estimate Report on Foreign Trade Barriers (http://www.ustr.gov/reports/ index.shtml), an annual analysis of impediments in other countries affecting US businesses. These include investment restrictions.

In addition, the US Commerce Department prepares a regular analysis of the business environment in foreign countries in its Country Commercial Guide 
(http://strategis.ic.gc.ca/epic/internet/inimr-ri2.nsf/en/gr00001e.html). Each of these guides contains a chapter on the investment climate, which itself includes a section entitled 'Openness to Foreign Investment', which reports restrictions on FDI.

For electricity, the US Department of Energy's Country Commercial Briefs generally provide information on the extent of government and foreign ownership.

\section{e. Other Sources}

PricewaterhouseCoopers (PWC) has a Doing Business and Investing in Countries Worldwide CD (2001) with descriptions of barriers to foreign investors in a large number of countries.

For some countries, national sources were consulted, but the large number of countries in the sample precluded a systematic search of national sources.

\section{REFERENCES}

Arnold, J., A. Mattoo and G. Narcisco (2006), 'Services Inputs and Firm Productivity in SubSaharan Africa: Evidence from Firm-level Data', World Bank Working Paper No. WPS4048, November (Washington, DC: World Bank).

Arnold, J., B. S. Javorcik and A. Mattoo (2007), 'Does Service Liberalization Benefit Manufacturing Firms? Evidence from the Czech Republic', World Bank Working Paper No. WPS4109, January (Washington, DC: World Bank).

Golub, S. S. (2003), 'Measures of Restrictions on Inward Foreign Direct Investment for OECD Countries', OECD Economic Studies, 36, 2003/I, 85-116.

Golub, S. S., R. W. Jones and H. Kierzkowski (2007), 'Globalization and Country-specific Service Links', Journal of Economic Policy Reform, 10, 2, 63-88.

Graham, E. M. (2000), Fighting the Wrong Enemy: Antiglobal Activists and Multinational Enterprises (Washington, DC: Institute for International Economics).

Hardin, A. and L. Holmes (1997), 'Service Trade and Foreign Direct Investment', Industry Commission Staff Research Paper (Canberra: Australian Productivity Commission), available at: http://www.pc.gov.au/ic/research/information/servtrad/index.html.

Hardin, A. and L. Holmes (2002), 'Measuring and Modelling Barriers to FDI', in B. Bora (ed.), Foreign Direct Investment: Research Issues (London: Routledge), pp. 252-72.

Hoekman, B. (1995), 'Assessing the General Agreement on Trade in Services', in W. Martin and L. A. Winters (eds.), The Uruguay Round and the Developing Countries (Cambridge: Cambridge University Press), pp. 88-124.

Kalirajan, K. (2000), 'Restrictions on Trade in Distribution Services' (Canberra: Australian Productivity Commission).

Kobrin, S. (2005), 'The Determinants of Liberalization of FDI Policy in Developing Countries: A Cross-sectional Analysis, 1992-2001', Transnational Corporations, 14, 1, 67-104.

Koyama, T. and S. S. Golub (2006), 'OECD's FDI Regulatory Restrictiveness Index: Update and Extension to More Countries', Economics Department Working Paper No. 525 (Paris: OECD).

Markusen, J. R. and K. Maskus (2001), 'General Equilibrium Approaches to the Multinational Firm: A Review of Theory and Evidence', NBER Working Paper No. 8344 (Cambridge, MA: NBER).

McGuire, G. and M. Schuele (2001), 'Restrictiveness of International Trade in Banking Services', in C. Findlay and T. Warren (eds.), Impediments to Trade in Services: Measurement and Policy Implications (New York: Routledge), pp. 201-14. 
McGuire, G., M. Schuele and T. Smith (2001), 'Restrictiveness of International Trade in Maritime Services', in C. Findlay and T. Warren (eds.), Impediments to Trade in Services: Measurement and Policy Implications (New York: Routledge), pp. 172-88.

Moran, T. H., E. M. Graham and M. Blomström (eds.) (2005), Does Foreign Direct Investment Promote Development? (Washington, DC: Institute for International Economics).

Nguyen-Hong, D. (2000), 'Restrictions on Trade in Professional Services' (Canberra: Australian Productivity Commission).

OECD (various years), Investment Policy Reviews (Paris: OECD).

OECD (1982), Controls and Impediments Affecting Inward Direct Investment in OECD Member Countries (Paris: OECD).

OECD (1987), Controls and Impediments Affecting Inward Direct Investment in OECD Member Countries (Paris: OECD).

OECD (1992), International Direct Investment: Policies and Trends in the 1980s (Paris: OECD).

OECD (2005a), National Treatment of Foreign Controlled Enterprises (Paris: OECD).

OECD (2005b), 'Regulatory Environment for FDI in African Countries', available at: http:// www.oecd.org/dataoecd/25/6/34783838.pdf.

Pacific Economic Cooperation Council (PECC) (1995), Survey of Impediments to Trade and Investment in the APEC Region (Singapore: PECC).

Robertson, D. (2002), 'Multilateral Investment Rules', in B. Bora (ed.), Foreign Direct Investment: Research Issues (New York: Routledge), pp. 310-24.

Sauvé, P. and C. Wilkie (2000), 'Investment Liberalisation in GATS', in P. Sauvé and R. M. Stern (eds.), GATS 2000: New Directions in Services Trade Liberalisation (Washington, DC: Brookings Institution Press), pp. 331-63.

UNCTAD (various years), Investment Policy Reviews, available at: http://www.unctad.org/ Templates/StartPage.asp?intItemID $=2554$

UNCTAD (2003), World Investment Report 2003 (Geneva: UNCTAD).

UNCTAD (2004), World Investment Report 2004 (Geneva: UNCTAD).

UNCTAD (2006), 'Measuring Restrictions on FDI in Services in Developing Countries and Transition Economies', UNCTAD Current Studies on FDI and Development No. 2 (Geneva: UNCTAD).

UNCTAD (2007), World Investment Report 2007 (Geneva: UNCTAD).

UNCTC (1989), Foreign Direct Investment and Transnational Corporations in Services (New York: United Nations).

Warren, T. (2001), 'The Identification of Impediments to Trade and Investment in Telecommunications Services', in C. Findlay and T. Warren (eds.), Impediments to Trade in Services: Measurement and Policy Implications (New York: Routledge), pp. 71-84. 